\title{
Deriving estimates of individual variability in genetic potentials of performance traits for 3 dairy breeds, using a model of lifetime nutrient partitioning
}

\author{
H. N. Phuong, ${ }^{*} \dagger^{1}$ O. Martin, ${ }^{*} \dagger$ I. J. M. de Boer, $\ddagger$ K. L. Ingvartsen, $\S$ Ph. Schmidely, ${ }^{\star} \dagger$ and N. C. Friggens ${ }^{*} \dagger$ \\ *INRA, UMR791 Modélisation Systémique Appliquée aux Ruminants, F-75005 Paris, France \\ †AgroParisTech, UMR791 Modélisation Systémique Appliquée aux Ruminants, F-75005 Paris, France \\ $\ddagger$ Animal Production Systems group, Wageningen University, PO 338, $6700 \mathrm{AH}$ Wageningen, the Netherlands \\ §Department of Animal Sciences, Faculty of Science and Technology, Aarhus University, DK-8830 Tjele, Denmark
}

\section{ABSTRACT}

This study explored the ability of an existing lifetime nutrient partitioning model for simulating individual variability in genetic potentials of dairy cows. Generally, the model assumes a universal trajectory of dynamic partitioning of priority between life functions and genetic scaling parameters are then incorporated to simulate individual difference in performance. Data of 102 cows including 180 lactations of 3 breeds: Danish Red, Danish Holstein, and Jersey, which were completely independent from those used previously for model development, were used. Individual cow performance records through sequential lactations were used to derive genetic scaling parameters for each animal by calibrating the model to achieve best fit, cow by cow. The model was able to fit individual curves of body weight, and milk fat, milk protein, and milk lactose concentrations with a high degree of accuracy. Daily milk yield and dry matter intake were satisfactorily predicted in early and mid lactation, but underpredictions were found in late lactation. Breeds and parities did not significantly affect the prediction accuracy. The means of genetic scaling parameters between Danish Red and Danish Holstein were similar but significantly different from those of Jersey. The extent of correlations between the genetic scaling parameters was consistent with that reported in the literature. In conclusion, this model is of value as a tool to derive estimates of genetic potentials of milk yield, milk composition, body reserve usage, and growth for different genotypes of cow. Moreover, it can be used to separate genetic variability in performance between individual cows from environmental noise. The model enables simulation of the effects of a genetic selection strategy on lifetime efficiency of individual cows, which has a main advantage of including the rearing costs, and thus, can be used to explore the

Received April 18, 2014

Accepted October 1, 2014.

${ }^{1}$ Corresponding author: phuong.hongoc@agroparistech.fr impact of future selection on animal performance and efficiency.

Key words: nutrient partitioning, dairy cow, genetic variability, dynamic model

\section{INTRODUCTION}

Milk production efficiency is affected by the way in which dairy cows partition obtained nutrients between life functions. Generally, an efficient cow should allocate a greater proportion of nutrients toward the mammary gland, for milk synthesis (Linn et al., 2009). This traditional view of efficiency is based on the concept of dilution of maintenance; that is, when a cow eats more feed to support milk production a smaller proportion is used for maintenance and is thus more efficient (Bauman et al., 1985). However, if efficiency is considered over the lifespan of an animal, the extent to which nutrients are partitioned to vital functions such as health and fertility is important because the longer the productive life the smaller is the rearing phase as a proportion, and thus greater the lifetime efficiency. These vital functions are not only related to economic (Collard et al., 2000) and environmental issues (Garnsworthy, 2004), but animal welfare (Oltenacu and Algers, 2005). Thus, being able to predict the nutrient partitioning process of cows can help improve animal efficiency and farm profitability, and reduce environmental impact.

Pioneering works of Baldwin et al. (1987a,b) and Oldham and Emmans (1989) show that mathematical models can be used to explore concepts and hypotheses, regarding nutrient partitioning in dairy cows, and have potential for predicting long-term efficiency (Dumas et al., 2008; Friggens et al., 2013). Clear genetic differences exist in nutrient partitioning between cows (Yan et al., 2006) and physiological states (Kirkland and Gordon, 2001). Thus, prediction of nutrient partitioning should consider genetic variability between cows and differences in expression of their genotypes through time. By capturing these ideas, the model of Martin and Sauvant (2010a) is able to simulate the average 
pattern of dynamic partitioning of energy intake and performance through lifespan of cows of different yield levels, and thus allows genetic variability to be incorporated in prediction of lifetime efficiency. This model assumes a general trajectory of dynamic partitioning of a cow's relative priority between life functions, and genetic scaling parameters are then incorporated to scale individual performance, and to simulate variability between genotypes in, for example, milk production. In other words, it assumes that performance of animals differs only in terms of scaling but not in terms of the dynamic shape.

At this moment, however, the appropriateness of the model to realistically simulate individual variability in nutrient partitioning trajectories is untested. Though the model shows a good fit to the mean values of various population data from literature (Schutz et al., 1990; Hoffman, 1997), the extent to which the assumption of one general trajectory of dynamic partitioning of relative priority still holds when comparing different genotypes should be validated. Does the trajectory of dynamic partitioning of relative priority differ between breeds kept in the same environment? It is also important to evaluate the individual variation in genetic scaling parameters and their possible correlations and factors affecting them. Such information is necessary for setting up realistic population simulations and, in the wider context, for using the model to simulate the effects on lifetime efficiency of possible selection and management strategies.

The aim of this study was, therefore, to examine the model of Martin and Sauvant (2010a) for its capability of simulating individual variability in genetic potentials of milk yield (MY), milk composition, growth, and body reserve usage of different genotypes of cow.

\section{MATERIALS AND METHODS}

For clarity, it should be noted that this paper dealt with the situation where cows are managed in a nonconstraint environment (i.e., unlimited access to a high quality feed, water or neutral ambient temperature), and thus, the performance profiles that a given cow would achieve in such an environment is referred to as genetic potential, in accordance with literature definitions of genetic potential (e.g., Oldham and Emmans, 1989).

\section{Teleonomic Model (GARUNS)}

This section presents a brief introduction to the teleonomic model of Martin and Sauvant (2010a). This teleonomic model, referred to here as GARUNS, consists of a regulating submodel providing a driving force to control the function of an operating submodel. An adapted scheme of GARUNS is presented in Figure 1. The regulating submodel describes the dynamic partitioning of a female mammal's priority between life functions: growth $(\mathbf{G})$, aging $(\mathbf{A})$, regaining of body reserves $(\mathbf{R})$, and energy supply of the unborn $(\mathbf{U})$, newborn $(\mathbf{N})$, and suckling $(\mathbf{S})$ calf over a lifespan. This dynamic pattern of priorities is assumed to be general for all individual cows. The sum of these relative priorities is always equal to one. The operating submodel uses the relative priorities to partition energy intake between fetal growth, BW and body composition, MY, and milk composition over the lifespan and during repeated reproductive cycles. Genetic scaling parameters are incorporated in the operating submodel to scale individual performance potentials of, for example, mature body size or milk production. It should be noted that these genetic scaling parameters are not simply related to the widely reported breeding values commonly used in the animal genetics literature. They act as multipliers on the different dynamic priorities and thus provide the means to create different levels of genetic potential performance for different cows. A general principle is that the higher the value genetic scaling parameter, the higher the genetic potential. In this context, the variation in genetic scaling parameters describes the variation in genetic potential between animals. In the model, an animal is described in terms of its genotype for growth, capacity to store and mobilize reserves, and milk production using the following genetic scaling parameters: nonlabile body mass at maturity $\left(\mathbf{W}_{\mathbf{M}}\right)$, rate of regaining body reserves per day $\left(\mathbf{b}_{0}\right)$, labile body mass mobilization index $\left(\boldsymbol{\nu}_{\mathbf{X}}\right)$, peak MY potential $\left(\boldsymbol{\nu}_{\mathbf{y}}\right)$, milk fat secretion $\left(\boldsymbol{\nu}_{\mathbf{F}}\right)$, milk protein secretion $\left(\boldsymbol{\nu}_{\mathbf{P}}\right)$, and milk lactose secretion $\left(\boldsymbol{\nu}_{\mathrm{L}}\right)$. The unit of $\mathrm{W}_{\mathrm{M}}$ is kilograms, whereas the remaining parameters are fractions and, therefore, have no unit. For example, for a reference Holstein cow $\left(\mathrm{W}_{\mathrm{M}}=500\right)$, the value of $\nu_{\mathrm{y}}$ of 1 represents peak MY of 24,29 , and $32 \mathrm{~kg} / \mathrm{d}$ in first, second, and third parities, respectively. Thus, to describe each genotype, a specific set of these genetic scaling parameters is needed, and noticeably they were the same throughout the lifespan of the animal. External triggers of successful insemination (i.e., conception) drive the changes between nonreproductive and reproductive states of the animal, cueing in the dynamic priority trajectories described in the regulating submodel. As shown in Figure 1, the combination between dynamic priority and genetic scaling parameters makes it possible to quantify the total amount of energy required to fulfill all functions $\left(\boldsymbol{\Sigma}_{\mathbf{E}}\right)$. The resulting DMI is quantified by multiplying $\Sigma_{\mathrm{E}}$ with the predetermined dietary energy density $\left(\mathbf{e}_{\mathrm{D}}\right)$. The coefficients of energy partition to different life functions $\left(\mathrm{E}_{\mathrm{G}} / \Sigma_{\mathrm{E}}, \mathrm{E}_{\mathrm{R}} / \Sigma_{\mathrm{E}}, \mathrm{E}_{\mathrm{MY}} /\right.$ 


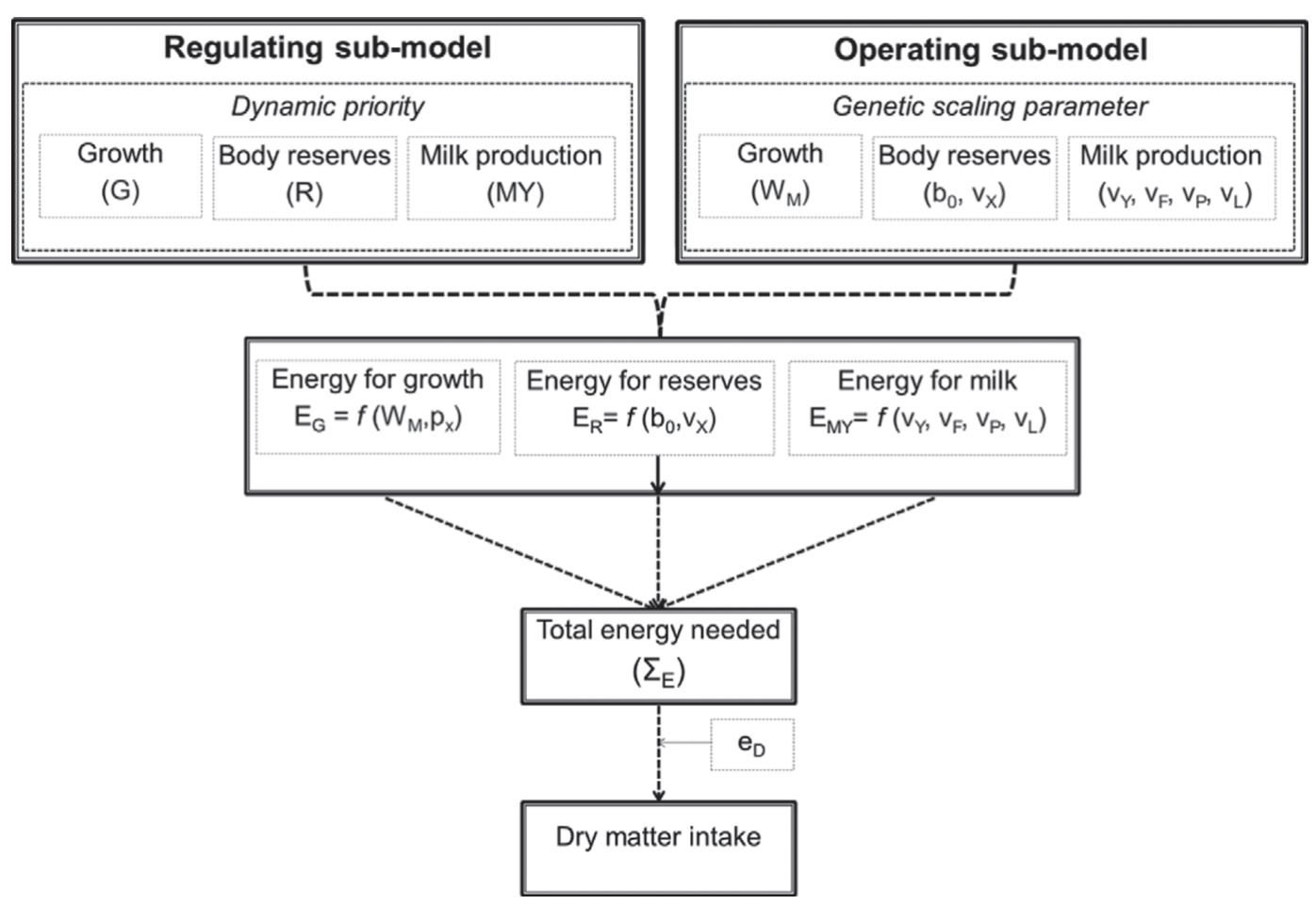

Figure 1. Schematic diagram representing the GARUNS model [Martin and Sauvant (2010)], showing how energy requirements for different life functions (growth, body reserves, and milk) are derived from genetic scaling parameters combined with lifetime profiles of relative priorities for the different life functions. The priorities for fetal growth, aging (in regulating submodel), and energy needed for fetal growth (in operating submodel) are not presented because they are assumed to be common trajectories for every individual. Total energy needed is the sum of the different requirements, from which DMI can be calculated assuming an appropriate diet energy density $\left(\mathrm{e}_{\mathrm{D}}\right)$.

$\Sigma_{\mathrm{E}}$, where $\mathrm{E}_{\mathrm{G}}, \mathrm{E}_{\mathrm{R}}, \mathrm{E}_{\mathrm{MY}}$ are energy required for growth, reserves storage, and milk production, respectively) are the result of the interactions between dynamic partitioning priorities and genetic scaling parameters.

\section{Animal Data}

Data used in this study were obtained from an experiment conducted at Aarhus University, Denmark from January 1996 to October 2001. The experiment has been described in detail in Nielsen et al. (2003). Briefly, 3 dairy cow breeds (Danish Red, Danish Holstein and Jersey) were used. A total of 102 cows were used, including 180 lactations suitable for the present study. Cows were kept in a neutral ambient temperature and were fed the same total mixed ration ad libitum throughout lactation with an energy density that was assumed to allow the cows to fully express their genetic potentials (i.e., nonconstraining). The ingredients and chemical composition of the diet were described in Nielsen et al. (2003). The average DM content of the diet was $52 \%$ and the ME density of the diet $\left(\mathbf{e}_{\mathbf{D}}\right)$ was $11.1 \mathrm{MJ} / \mathrm{kg}$ of DM. Cows were milked twice daily, whereas MY and milk composition were recorded at each milking. All animals were weighed on d 2, 3, and 8 after calving and, subsequently, once a week until 3 mo after calving. From 3 mo after calving toward the dry period, they were weighed every 2 wk and once a week during the dry period. The health status of cows was also recorded (day of treatment, pre- and postperiod of treatment, and healthy periods). The cows were housed throughout the year in single tie stalls.

\section{Model Fitting}

The GARUNS model uses the description of an animal in terms of its genetic scaling parameter and its relative priorities to allow calculation of the amount of energy required to meet its performance potentials. Given predetermined characteristics of diet (i.e., energy density and DM content), this average requirement can be converted to an estimate of DMI. The starting point of this approach is potential performance, and it can be termed as "potential output drives intake" (Emmans and Kyriazakis, 2001), which is opposite to the approach described by, for instance, Baldwin et al. (1987a,b) where the starting point is a given feed intake. It is, therefore, reasonable to fit the model with observed BW and MY, and consider DMI as the consequence. Moreover, because GARUNS assumes a 
general trajectory of dynamic partitioning according to the relative priority to different life functions, we hypothesized no systematic difference between predicted and observed animal performances.

The inputs of GARUNS are classified as reproductive timing [age at first conception $\left(\mathbf{P C I}_{\mathbf{0}}\right)$, and parturition to conception interval $\left(\mathbf{P C I}_{\mathbf{c}}\right)$, where c is reproductive cycle number], and dietary characteristics ( $\mathrm{e}_{\mathrm{D}}$ and $\left.\mathrm{DM}\right)$. The $\mathrm{PCI}_{c}, \mathrm{e}_{\mathrm{D}}$, and $\mathrm{DM}$ were obtained directly from the database. No records on $\mathrm{BW}, \mathrm{PCI}_{0}$, and pregnancy length were available until first calving in the current database. It was, therefore, necessary to assume that all cows have the same age at first conception and a standard pregnancy length, and thus age at first calving. In other words, we adopted the shape of BW curve during the growing period of GARUNS, which has been previously calibrated using the GARUNS database (Martin and Sauvant, 2010a). This is justified because the model is designed to accommodate differences in growth performance between individual cows only in terms of scaling and not in terms of the shape of the performance profile. In this context, the scaling difference in BW of different animals is modulated by $\mathrm{W}_{\mathrm{M}}$. In terms of milk production, it was hypothesized by Martin and Sauvant (2010a) that peak MY of a cow increases linearly by parity for all cows. However, it seemed reasonable to examine this assumption in the present data set. To address this issue a new parameter $\left(v_{\text {ypi }}\right)$ was introduced to modulate the priority for milk production independently in each parity, where i is parity; $\nu_{\mathrm{ypi}}$ is relative deviation of priority for milk production in parity i from the lifetime $v_{\mathrm{y}}$. It was assumed that no deviation happens in first parity (i.e., $\nu_{\text {yp } 1}$ is equal to $1)$. In this context, the priority for milk production in parity $\mathrm{i}\left(\nu_{\mathrm{yi}}\right)$ is equal to $\nu_{\text {ypi }}$ multiplied by $\nu_{\mathrm{y}}$. The DMI is the function of total energy requirement $\left(\Sigma_{\mathrm{E}}\right)$ and a predetermined $\mathrm{e}_{\mathrm{D}}$.

\section{Model Fitting to Individual Data}

To derive individual genetic scaling parameters, the model was used to adjust these parameter values for each cow so as to achieve best fit with the observed performance data through sequential lactations of that cow. This calibration process was done individually, cow by cow, and once the best fit was obtained the genetic scaling parameters were recorded for that cow. It should be noted that the data used for estimating these genetic scaling parameters were different from the one used to develop and parameterize GARUNS. The model calibration was implemented and optimized with the Modelmaker software version 3.0 (Cherwell Scientific Ltd., 2000), using the Runge-Kutta 4 numerical integration procedure and a fixed integration step of 1 d. The numerical values of the genetic scaling parameters were estimated for each individual cow data series (from first to last parity) using a least square procedure performed with the simplex algorithm of Modelmaker to derive best fit parameters, with default parameter values and 100 convergence steps.

\section{Model Evaluation}

The ability of the GARUNS model to fit the observed data was evaluated using the root mean square error (RMSE), computed as follows:

$$
\mathrm{RMSE}=\sqrt{\frac{1}{\mathrm{~N}} \sum_{\mathrm{i}=1}^{\mathrm{N}}\left(\mathrm{O}_{\mathrm{i}}-\mathrm{P}_{\mathrm{i}}\right)^{2}},
$$

where $\mathrm{O}_{\mathrm{i}}$ and $\mathrm{P}_{\mathrm{i}}$ are the ith observed and predicted values of BW, MY, DMI, milk fat concentration (MCF), milk protein concentration (MCP), and milk lactose concentration (MCL), and $\mathrm{N}$ is the number of observations. The RMSE was calculated for each DIM across the $\mathrm{N}$ cows within each parity. The relative prediction error (RPE) was then computed as $100 \times$ RMSE/ (mean of the observed data). Values of RPE less than $10 \%$, between 10 and $20 \%$, and more than $20 \%$ indicate good, moderate, and poor prediction, respectively (Fuentes-Pila et al., 1996).

To examine the GARUNS assumption that the trajectory of dynamic partitioning of relative priority between life functions is general for all individuals, irrespective of breeds, mixed effect models were used. We hypothesized that, if the assumption is adequate, the slope of the regression between the residuals of prediction, (i.e., $\mathrm{O}_{\mathrm{i}}-\mathrm{P}_{\mathrm{i}}$ ), versus day from calving, should not be significantly different from zero, nor should there be any breed effect on the slope. The general form of the mixed model used to analyze residuals was

$$
\begin{aligned}
\mathrm{Y}_{\mathrm{ijk}} & =\mu+\alpha_{\mathrm{i}} \mathrm{DFC}_{\mathrm{i}}+\beta_{\mathrm{j}} \text { Breed }_{\mathrm{j}}+\lambda_{\mathrm{ij}} \mathrm{DFC} \\
& \times \text { Breed }_{\mathrm{ij}}+\delta_{\mathrm{i}} \mathrm{DFC}_{\mathrm{i}}^{2}+\gamma_{\mathrm{k}}+\varepsilon_{\mathrm{ijk}},
\end{aligned}
$$

where $Y_{\mathrm{ijk}}$ are the GARUNS model fitting residuals of $\mathrm{BW}, \mathrm{MY}, \mathrm{MCF}, \mathrm{MCP}, \mathrm{MCL}$, and DMI; $\mu$ is the overall intercept across animals; $\alpha_{\mathrm{i}}, \beta_{\mathrm{j}}, \lambda_{\mathrm{ij}}$, and $\delta_{\mathrm{i}}$ are regression coefficients of $\mathrm{Y}$ on the corresponding predictors of day from calving (DFC), breed, interaction between DFC and breed, and squared DFC, respectively; $\gamma_{\mathrm{k}}$ is the random effect of kth animal; $\varepsilon_{\mathrm{ijk}}$ is the residual error, which was assumed to be normally distributed with mean of 0 and variance of $\sigma_{e}^{2}$; i is the number of days from calving; $\mathrm{j}$ is the number of breeds; and $\mathrm{k}$ is the number of animals. Given the high numbers of observations in these regressions, and therefore, the high test 
power (Lin et al., 2013) at the level of the regression coefficients, significant effects of breed were evaluated between models with and without breed included. Thus, $F$-values were computed as $\left[\left(\mathrm{RSS}_{2}-\mathrm{RSS}_{1}\right) /\left(\mathrm{p}_{1}\right.\right.$ $\left.\left.-\mathrm{p}_{2}\right)\right] /\left[\mathrm{RSS}_{1} /\left(\mathrm{n}-\mathrm{p}_{1}\right)\right]$ to compare model [1] and the general model having the following form:

$$
\mathrm{Y}_{\mathrm{ijk}}=\mu+\alpha_{\mathrm{i}} \mathrm{DFC}_{\mathrm{i}}+\delta_{\mathrm{i}} \mathrm{DFC}^{2}{ }_{\mathrm{i}}+\gamma_{\mathrm{k}}+\varepsilon_{\mathrm{ijk}} .
$$

The differences between model [2] and model [1] were the removal of Breed and Breed $\times$ DFC interaction effects. The $\mathrm{RSS}_{1}$ is residual sum of square of model [1], $\mathrm{RSS}_{2}$ is residual sum of square of model [2], $\mathrm{p}_{1}=7$ is the number of parameters in model [1], $\mathrm{p}_{2}=3$ is the number of parameters in model [2], and $\mathrm{n}$ is the number of animals ( $\mathrm{n}=81$ or 65 or 27 for first or second or third parity, respectively). Consequently, $\left(\mathrm{p}_{1}-\mathrm{p}_{2}\right)$ was the numerator degree of freedom, and $\left(\mathrm{n}-\mathrm{p}_{1}\right)$ was the denominator degree of freedom. The $F$-values were computed individually for MY, BW, DMI, MCF, MCP, and MCL. Subsequently, $F$-values were compared with critical $F$-values from the $F$-table using corresponding nominator and denominator degree of freedom, and a significance level of 0.05 . If the 2 models are not significantly different, it can be concluded that data for 3 breeds can be fitted using simple models with general intercepts and slopes (i.e., model [2]). In other words, any deviations between breeds must be small and the observed significant differences could simply be the consequence of having a large number of observations. To reduce the correlations between intercept and slope, data of DFC were centered on the mean.

The correlations between genetic scaling parameters and the similarities between breeds were explored using principal components (PC) analysis. Mixed effect models and PC analysis were performed using nlme and FactoMineR packages of the statistical software $\mathrm{R}$ version 2.5.2 (R Development Core Team, 2014).

\section{RESULTS}

\section{General Quality of Model Fitting}

An example of model simulations of BW, MY, and milk composition plotted with observed values for the first 2 parities is presented in Figure 2. Tables 1 and 2 present the means of observed values for BW, MY, DMI, MCF, MCP, and MCL together with RPE values. The results are shown for 3 periods within parity and breed (wk 1-15, 16-35, and 36-45). Because very few observations were made after 45 wk of lactation, they were excluded from the calculations of RMSE and RPE. In general, the accuracy of predictions for BW, MY, and DMI improved slightly in parity 2 and
3 compared with parity 1 , which was not the case for milk composition. The accuracies for predicting performance of Danish Red, Danish Holstein, and Jersey were similar. The GARUNS accurately predicted individual BW, MCF, MCP, and MCL over 3 parities, which was demonstrated by the low values of RPE $(<13 \%)$. The MY and DMI were acceptably predicted in early- and mid-lactation (RPE <20\%), but poorly predicted in the end of lactation $(\mathrm{RPE}>20 \%)$. The late-lactation period, however, contributed on average only $7 \%$ to the total lactation yield of MY and $13 \%$ to the total DMI. We also explored the change of prediction accuracy within parity by examining the relationship between daily values of RPE across all animals versus day in milk. It turns out that the prediction accuracy tended to be lower during the first 4 wk and last 8 wk. The relative magnitudes of deviations were, moreover, smaller for BW, MCF, MCP, and MCL compared with MY and DMI.

\section{Evaluation of Residuals for Time Patterns}

Plots of GARUNS fitting residuals (observed - predicted) relative to DFC are shown in Figure 3. The aim of the regression analysis was to evaluate if the GARUNS assumption still holds for different breeds. Thus, it was hypothesized that the slopes of regression lines between individual residual versus day from calving should not be significantly different from zero. Given that the data were centered, the significances of the intercepts are no longer important because they are not primary indicators of a systematic time trend of residuals. The results of the multiple regression analysis relating the residuals from fitting the GARUNS model to observed data to days from calving for BW, MY, DMI, and milk composition are shown in the Appendix (Tables A1 and A2). The significant linear and curvilinear (DFC and $\mathrm{DFC}^{2}$ ) effects indicate a systematic difference between the shape assumed by GARUNS and that of the database used in this study. The curvilinear effect can be seen from Figure 2 or the values of $\mathrm{RPE}$ in the last stage of lactation cycle (Tables 1 and 2 ). Linear slope differences were found between breeds, which could suggest that the key assumption of the GARUNS model does not hold for different breeds. We, however, suspected these significant differences might simply be the consequence of having a large number of observations in the test (e.g., $\mathrm{n}=20,136$ for MY). Indeed, the comparison between the full model with inclusion of breed effect (model [1]) and the simple model without inclusion of breed effect (model [2]) showed no significant improvement in the capability of model fit by including breed. The $F$-values for fitting residuals of MY, BW, DMI, MCF, MCP, and MCL in parity 1 

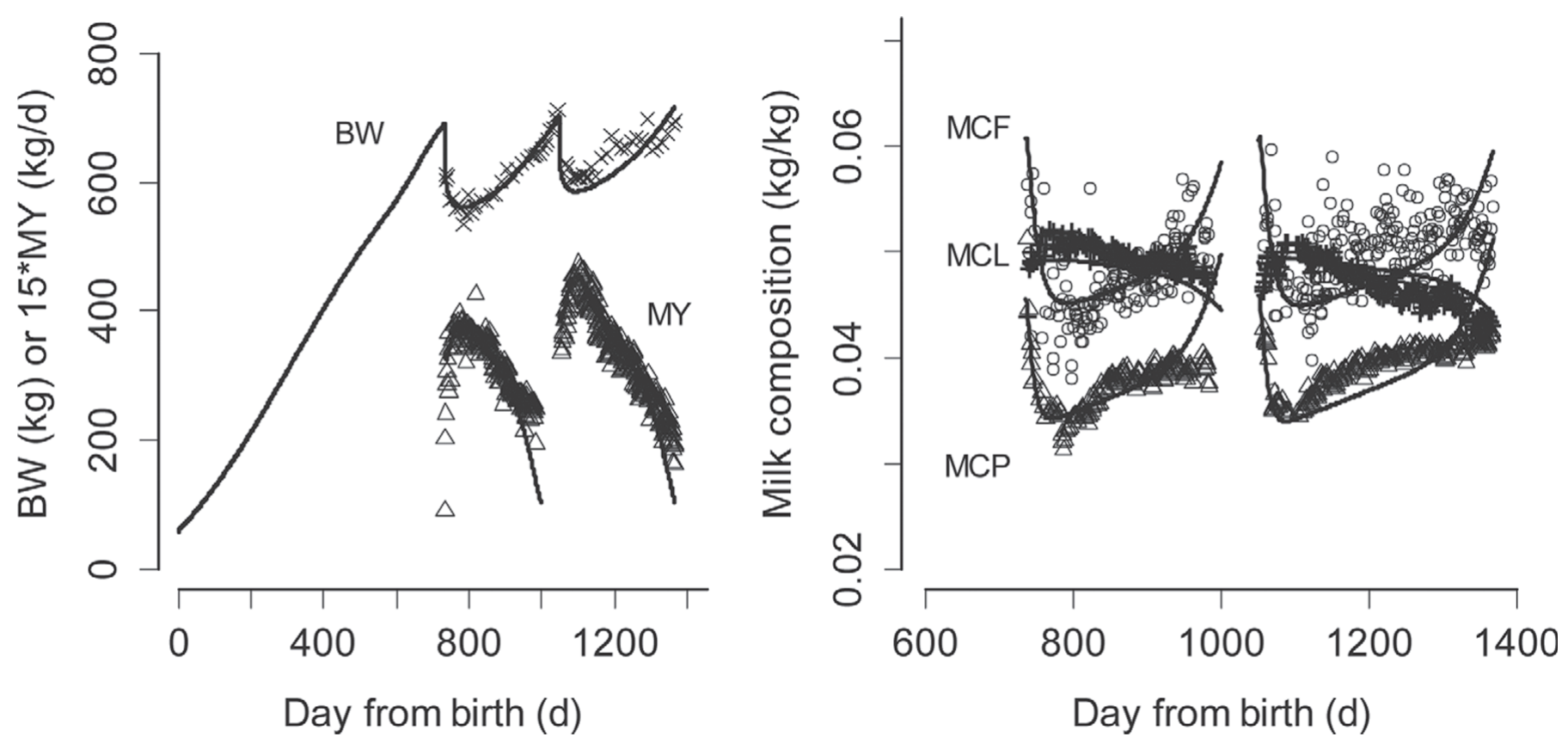

Figure 2. Model simulations (solid line) of BW ( $\mathrm{kg}$ ), milk yield ( $\mathrm{MY}, \mathrm{kg} / \mathrm{d}$ ), milk fat concentration $(\mathrm{MCF}, \mathrm{kg} / \mathrm{kg}$ ), milk protein concentration $(\mathrm{MCP}, \mathrm{kg} / \mathrm{kg}$ ), and milk lactose concentration (MCL, $\mathrm{kg} / \mathrm{kg}$ ) in first 2 lactations of a selected cow plotted with actual observations (symbol). For clarity of presentation, MY is shown as MY $\times 15$.

varied from 0.10 to 1.07 , which are considerably smaller than the value of $F$-critical of 2.53 at the level of significance of 0.05 . Additionally, the residual standard deviations of model [1] and model [2] were very similar [i.e., MY (2.44 vs. 2.50), BW (17.22 vs. 17.28), DMI (3.10 vs. 3.11$), \mathrm{MCF}(0.045$ vs. 0.046$), \mathrm{MCP}(0.002$ vs. 0.002), and MCL (0.001 vs 0.001)]. These results generally imply evidence of shape differences, but the differences were very small and not important in the context of using the teleonomic model (GARUNS) for simulation studies.

\section{Relationship Between Model Parameters}

The summary statistics for the genetic scaling parameters are shown in Table 3. Large variations were present in genetic parameters modulating $\mathrm{BW}$ of the animals (i.e., $\mathrm{W}_{\mathrm{M}}, \mathrm{b}_{0}$, and $\nu_{\mathrm{x}}$ ), which represented 23 , 25 , and $39 \%$ of their means, respectively. The relative variations of parameters modulating $\mathrm{MY}$ and milk composition were less than $20 \%$. No significant differences were found between 3 breeds in the means of $b_{0}$ and $\nu_{\mathrm{L}}(P>0.05$, statistics not reported). The mean values of the remaining genetic parameters $\left(\mathrm{W}_{\mathrm{M}}, \nu_{\mathrm{x}}\right.$, $\nu_{\mathrm{y}}, \nu_{\mathrm{F}}$, and $\nu_{\mathrm{p}}$ ) were similar between Danish Red and Danish Holstein $(P>0.05)$, but significantly different from those of Jersey. The correlations between genetic parameters were initially explored within each breed (data not shown). Generally, few significant correlations were found except for the following: $\mathrm{W}_{\mathrm{M}}$ was negatively correlated with $\nu_{\mathrm{y}}(\mathrm{r} \approx-0.50) ; \nu_{\mathrm{y}}$ was negatively correlated with $\nu_{\mathrm{F}}, \nu_{\mathrm{p}}$, and $\nu_{\mathrm{L}}(\mathrm{r}=-0.20$ to -0.61$)$; positive correlations were observed between $\nu_{\mathrm{F}}$ and $\nu_{\mathrm{p}}(\mathrm{r}=0.53$ to 0.83$)$, and between $\nu_{\mathrm{p}}$ and $\nu_{\mathrm{L}}(\mathrm{r}=0.35$ to 0.57$)$. The relationships between genetic scaling parameters were further explored with PC analysis, and are shown in Figures 4 and 5 . The first $2 \mathrm{PC}$ accounted for $56.1 \%$ of the total variation, whereas the inclusion of third and fourth PC increased variation accounted up to $87.1 \%$. The variables that are close together are strongly correlated (e.g., $\nu_{\mathrm{P}}$ and $\left.\nu_{\mathrm{F}}\right)$. The loadings coefficients for each variable and each $\mathrm{PC}$ are presented in Table 4 . Loadings coefficients $(\mathbf{w})$ describe the weight or the position of variables in each PC. Principal component 1 distinguishes dairy cows with a high BW $(\mathrm{w}=-0.74)$ and low concentrations of milk protein and milk fat from those with a low BW and high concentrations of milk protein $(\mathrm{w}=0.94)$ and milk fat $(\mathrm{w}=0.92)$. This is mainly identifying the difference between Jersey cows and the other breeds (Danish Holstein and Danish Red; Figure 4b). Principal component 2, independent from PC 1, indicates that high values of $\mathrm{BW}(\mathrm{w}=$ $0.56)$ and MCL $(\mathrm{w}=0.57)$ were associated with a low value of MY ( $\mathrm{w}=-0.86)$. Danish Holstein and Danish Red show some separation on PC 2 (Figure 4b). Principal component 3 separates animals with high ability of storage $(\mathrm{w}=0.86)$ from animals with high ability of mobilization of body reserves $(\mathrm{w}=-0.63)$. 
Table 1. GARUNS ${ }^{1}$ model accuracy for predicting BW, milk yield (MY), and DMI during 3 parities of 3 breeds: Danish Red, Danish Holstein, and Jersey $^{2}$

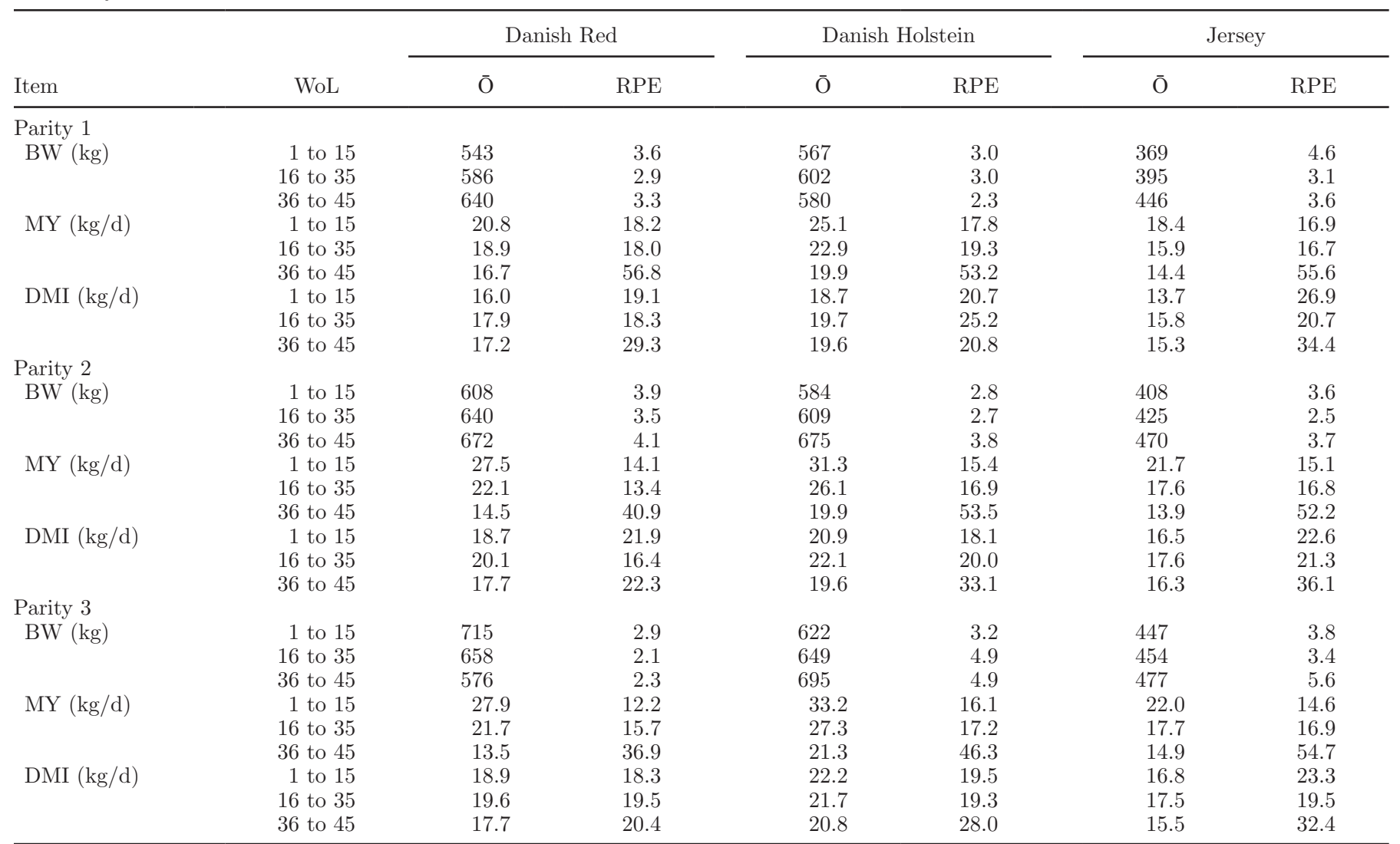

${ }^{1}$ Growth (G), aging (A), regaining of body reserves (R), and energy supply of the unborn (U), newborn (N), and suckling (S) calf over a lifespan. ${ }^{2} \mathrm{WoL}=$ week of lactation; $\overline{\mathrm{O}}=$ mean observed value; $\mathrm{RPE}=$ relative prediction error $(\%)$.

Principal components 3 and 4 probably indicate differences within breed. It is difficult to distinguish between breeds from Figure 5b, but it instead discriminates cows of high capability of mobilization from cows of high capability of storage. This may be identifying cows that have been selected for different purposes (i.e., milk production or milk-meat).

Figure 6 presents the priority for milk production in parity 2 relative to that in parity 1 . The slope of the regression line is significantly lower than $1(P<0.05)$ indicating a negative effect on milk production in parity 2 if it had been highly prioritized in the previous parity. Data from parity $3+$ were insufficient to examine this relationship in higher parities.

\section{DISCUSSION}

The GARUNS model was generally able to fit individual curves of BW, MCF, MCP, and MCL with a high degree of accuracy. Daily MY and DMI of individual cows were satisfactorily predicted in early- and midlactation, but significant underpredictions were found in late lactation. Breeds and parities did not influence the prediction accuracy. Further, the inclusion of a breed effect did not significantly improve the regression models to describe time trends in the residuals of GARUNS fitting (compared with the general regression models without inclusion of breed effect). Thus, the GARUNS model can be used to simulate performance of individual cows using the assumption that the shape of relative priorities is general, and the individual variability can be simply captured using genetic scaling parameters. The general underprediction of MY and DMI in late lactation would be explained by the difference in feeding system between the experiment of Nielsen at al. (2003) and the one that Martin and Sauvant (2010a) used for calibration (i.e., Schutz et al., 1990). Cows in the study of Nielsen et al. (2003) were fed with a constant energy density diet throughout lactation to allow cows to express their genetic potentials, whereas in Schutz et al. (1990) cows were fed with a step-down reduction of energy density diet from early to late lactation. This type of step feeding system is the most common one in current dairy practice (Erasmus et al., 2013; Stewart et al., 2014). The reduced dietary energy in late lactation probably results in a moderate lack of energy to allow 
Table 2. GARUNS ${ }^{1}$ model accuracy for predicting milk fat concentration (MCF), milk protein concentration (MCP), and milk lactose concentration (MCL) during 3 parities of 3 breeds: Danish Red, Danish Holstein, and Jersey ${ }^{2}$

\begin{tabular}{|c|c|c|c|c|c|c|c|}
\hline \multirow[b]{2}{*}{ Item } & \multirow[b]{2}{*}{ WoL } & \multicolumn{2}{|c|}{ Danish Red } & \multicolumn{2}{|c|}{ Danish Holstein } & \multicolumn{2}{|c|}{ Jersey } \\
\hline & & $\overline{\mathrm{O}}$ & $\mathrm{RPE}$ & $\overline{\mathrm{O}}$ & $\mathrm{RPE}$ & $\overline{\mathrm{O}}$ & $\mathrm{RPE}$ \\
\hline & 16 to 35 & 0.045 & 8.2 & 0.046 & 9.6 & 0.063 & 9.2 \\
\hline & 36 to 45 & 0.049 & 9.3 & 0.044 & 7.5 & 0.067 & 7.4 \\
\hline $\mathrm{MCP}(\mathrm{kg} / \mathrm{kg})$ & 1 to 15 & 0.037 & 10.0 & 0.037 & 8.2 & 0.038 & 8.1 \\
\hline \multirow[t]{3}{*}{ MCL $(\mathrm{kg} / \mathrm{kg})$} & 1 to 15 & 0.048 & 4.2 & 0.049 & 4.9 & 0.049 & 3.1 \\
\hline & 16 to 35 & 0.048 & 2.8 & 0.047 & 3.2 & 0.047 & 2.9 \\
\hline & 36 to 45 & 0.048 & 7.8 & 0.049 & 3.2 & 0.047 & 6.1 \\
\hline \multicolumn{8}{|l|}{ Parity 2} \\
\hline \multirow[t]{3}{*}{$\mathrm{MCF}(\mathrm{kg} / \mathrm{kg})$} & 1 to 15 & 0.046 & 13.5 & 0.044 & 13.1 & 0.057 & 11.6 \\
\hline & 16 to 35 & 0.047 & 8.7 & 0.044 & 7.8 & 0.064 & 10.1 \\
\hline & 36 to 45 & 0.051 & 10.1 & 0.050 & 10.0 & 0.070 & 7.6 \\
\hline MCL (kg/kg) & 36 to 45 & 0.044 & 3.5 & 0.045 & 5.0 & 0.046 & 5.7 \\
\hline \multicolumn{8}{|l|}{ Parity 3} \\
\hline \multirow{3}{*}{$\mathrm{MCF}(\mathrm{kg} / \mathrm{kg})$} & 1 to 15 & 0.050 & 9.4 & 0.046 & 12.1 & 0.058 & 11.8 \\
\hline & 16 to 35 & 0.047 & 10.3 & 0.043 & 8.6 & 0.065 & 9.4 \\
\hline & 36 to 45 & 0.051 & 9.1 & 0.048 & 11.7 & 0.067 & 10.8 \\
\hline \multirow[t]{3}{*}{$\mathrm{MCP}(\mathrm{kg} / \mathrm{kg})$} & 1 to 15 & 0.036 & 5.5 & 0.034 & 9.0 & 0.039 & 8.5 \\
\hline & 16 to 35 & 0.036 & 5.5 & 0.035 & 5.0 & 0.043 & 8.5 \\
\hline & 36 to 45 & 0.036 & 6.5 & 0.037 & 13.6 & 0.043 & 16.1 \\
\hline \multirow[t]{3}{*}{ MCL (kg/kg) } & 1 to 15 & 0.046 & 4.4 & 0.047 & 5.6 & 0.047 & 4.1 \\
\hline & 16 to 35 & 0.044 & 3.6 & 0.046 & 3.8 & 0.047 & 3.4 \\
\hline & 36 to 45 & 0.046 & 1.8 & 0.045 & 4.2 & 0.046 & 5.2 \\
\hline
\end{tabular}

${ }^{1}$ Growth $(\mathrm{G})$, aging $(\mathrm{A})$, regaining of body reserves (R), and energy supply of the unborn (U), newborn (N), and suckling (S) calf over a lifespan. ${ }^{2} \mathrm{WoL}=$ week of lactation; $\overline{\mathrm{O}}=$ mean observed value; $\mathrm{RPE}=$ relative prediction error $(\%)$.

cows to express their genetic potentials. Because maintenance has a higher priority than other needs (Jokela and Mutikainen, 1995; Heino and Kaitala, 1999), and because in late lactation body reserves are recovered with high priority to prepare for the next reproductive cycle, a shortage of energy would result in an impaired MY (Friggens, 2003). The high accuracy of predicting BW supports this argument. Given that GARUNS is a systemic model with separate parameters controlling the dynamic of partitioning priorities and the scaling of these according to different genetic potentials, it has the flexibility to be easily recalibrated to reflect the late lactation differences highlighted with the present data set. These results confirm the acceptability of using this teleonomic model for simulating lifetime performance of individual cows. They also suggest the data set used in this study is a good one for estimating genetic scaling parameters representing genetic potentials that are unaffected by any correlations between lactation stage and environment.

It has commonly been recognized that animals in the same population differ in their ability to perform, which comes as a result of variation in the nature of the animals or in the environment (Bryant et al., 2005). The data used in this study was obtained from a long-term genetic evaluation experiment where 3 breeds of cow selected for different purposes were kept in the same environment, thus making it appropriate for exploring the genetic variability between individuals. In this context, given that the GARUNS model fits the observed data well, it can be used to separate genetic variability in performance between individual cows from environmental noise. Moreover, it can, by individually calibrating the model, derive genetic scaling parameters representing genetic potentials of each cow. Characterizing individual variation in this way is valuable because it is a prerequisite for simulation studies. In the context where (nutritional) environment is under constraint, energy intake might be insufficient for animals to attain their genetic potentials; thus some functions might be given higher priority than others the rules for these adjustments are given in the companion publication of this model (Martin and Sauvant, 2010b).

To set up realistic population simulations it is important to acquire knowledge of variation and possible 

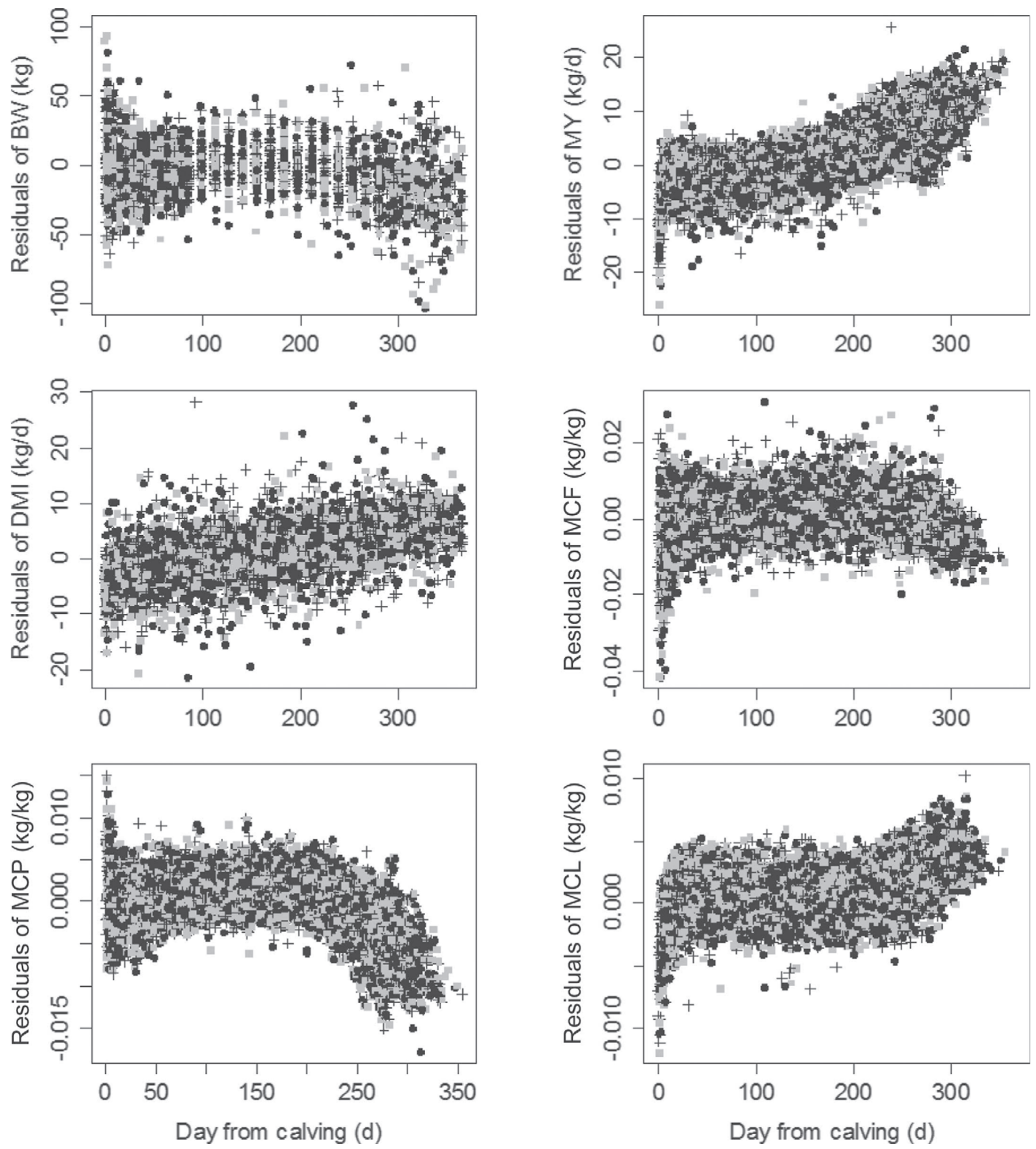

Figure 3. Distributions of individual residuals from GARUNS model fitting (observed - model fitted) for milk yield (MY), BW, DMI, milk fat concentration $(\mathrm{MCF})$, milk protein concentration (MCP), and milk lactose concentration (MCP) along day from calving in first parity of 3

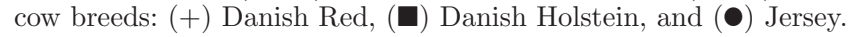


correlations between the model parameters (Emmans and Fisher, 1986). The summary statistics of genetic scaling parameters (Table 3) show no differences between Danish Red and Danish Holstein in the means of each parameter. Conversely, the means of genetic scaling parameters of Jersey were, with the exceptions of $\mathrm{b}_{0}$ and $\nu_{\mathrm{L}}$, significantly different from that of the other 2 breeds. The variation in $\nu_{\mathrm{L}}$ was significantly smaller than in any of the other parameters, implying a low potential for genetic change in MCL. This result is consistent with that of other studies (Welper and Freeman, 1992; Bedö et al., 1995).

In the GARUNS model, with the exception of $\mathrm{W}_{\mathrm{M}}$, each genetic scaling parameter modulates a particular trait independently. Thus, the correlations between these parameters would largely be induced by the biological relationships between the traits and not by the model structure as such. Not unexpectedly, some of the genetic scaling parameters were correlated (Figures 4 and 5). The results of the $\mathrm{PC}$ analysis also show that the model genetic scaling parameters were affected by genotypes. The first 2 components accounted for up to $56.1 \%$ of the total variation of the data and mainly distinguished the genetic differences between breeds (Figure 4). Generally, Danish Red and Danish Holstein breeds were represented by high BW and high milk production but low MCF and MCP. Jersey cows were characterized by small weight and high MCF and MCP. These results were consistent with the summary statistics on the means of genetic scaling parameters between the 3 breeds reported in Table 3. Further PC brought additional information on genetic variation within breeds. Within breed, negative correlations were found between the genetic scaling parameters for MY and milk composition (Figure 5). These results agree with other studies that reported genetic correlations ranging from -0.12 to -0.34 for $\mathrm{MY}$ versus $\mathrm{MCF},-0.18$ to -0.36 for MY versus MCP, and -0.08 for MY versus MCL (Welper and Freeman, 1992; Pantelić et al., 2008; Vallas et al., 2010). The strongly positive correlation between $\mathrm{MCF}$ and MCP agrees with the literature ranging from 0.51 to 0.56 (de Jager and Kennedy, 1987; Welper and Freeman, 1992). The relationship between MCL and $\mathrm{MCF}$ and MCP varied from 0.16 to 0.53 , whereas this has been reported between 0.11 and 0.29 (Welper and Freeman, 1992; Huhtanen, 2006). However, it should be noted that the relationships between the model parameters and correlations between traits reported from the literature might not be the same because they are not the direct measures of these traits but rather are representatives of those traits. The negative correlation between $\mathrm{W}_{\mathrm{M}}$ and $\nu_{\mathrm{y}}(\mathrm{r} \approx-0.50)$ does not agree with literature correlation between BW and MY. Genetic correlations between BW and MY are often weak or 
(a)

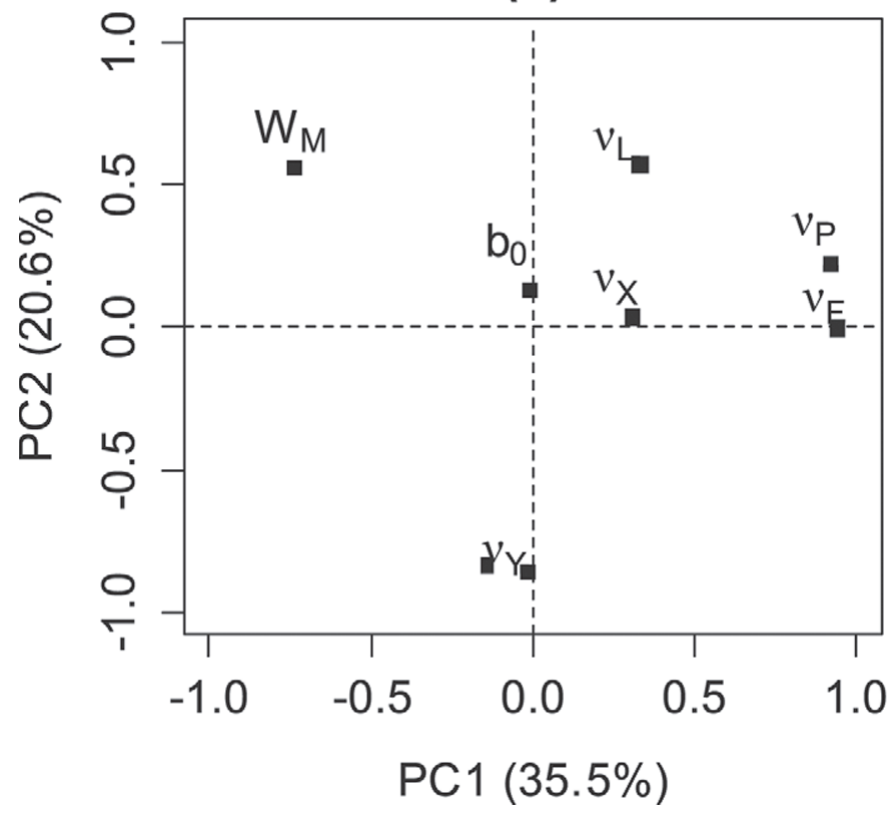

(b)

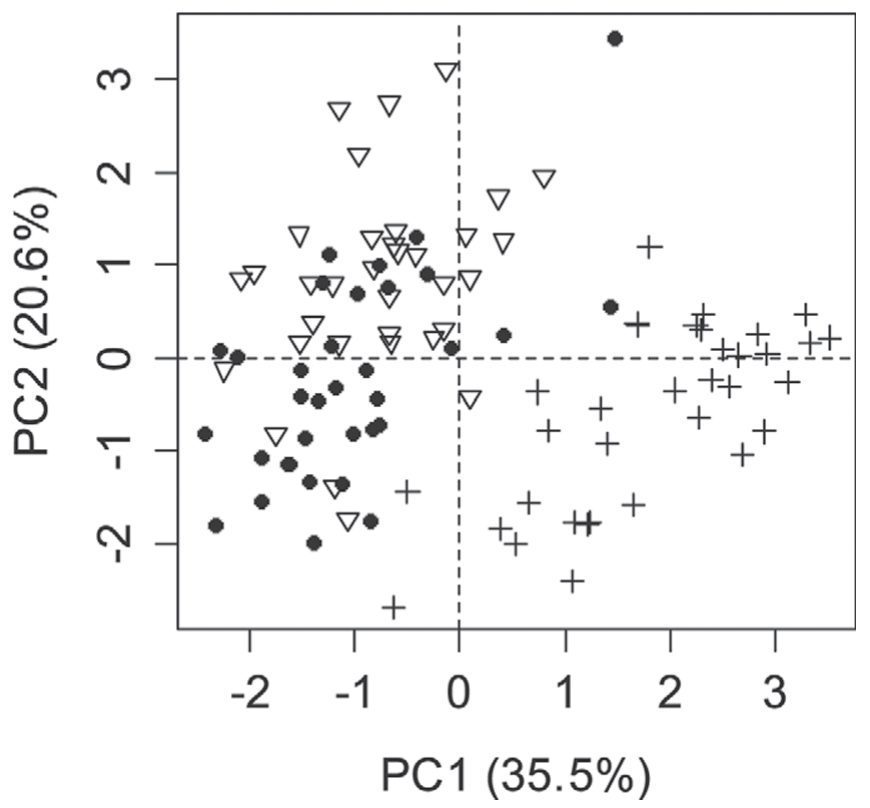

Figure 4. Principal component (PC) analysis loadings for PC 1 and PC 2 by variable (a), and scores for individual cows (b). In plot b, symbols are breeds: $(\nabla)$ Danish Red, $(\bullet)$ Danish Holstein, and $(+)$ Jersey. The variables included are genetic parameters for mature weight $\left(\mathrm{W}_{\mathrm{M}}\right)$, $\mathrm{b}_{0}=$ rate of regaining body reserves per day, $\nu_{\mathrm{X}}=$ labile body mass mobilization index, $\nu_{\mathrm{y}}=$ peak milk yield potential, $\nu_{\mathrm{F}}=$ milk fat secretion, $\nu_{\mathrm{P}}=$ milk protein secretion, and $\nu_{\mathrm{L}}=$ milk lactose secretion.

(a)

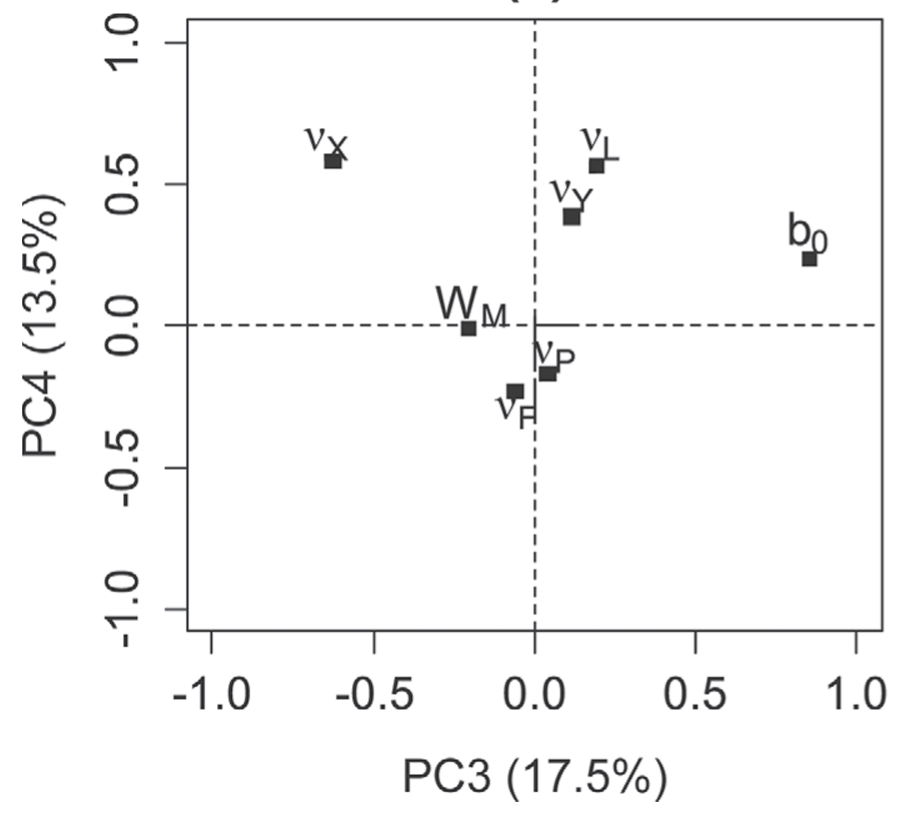

(b)

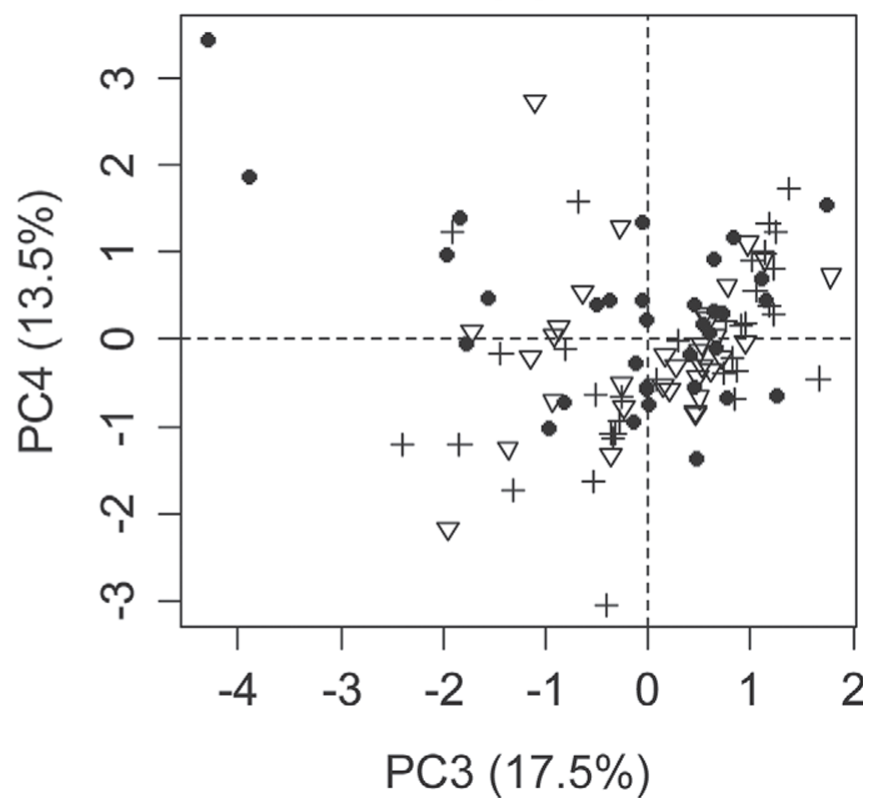

Figure 5. Principal component (PC) analysis loadings for PC 3 and PC 4 by variable (a), and scores for individual cows (b). In plot b, symbols are breeds: $(\nabla)$ Danish Red, $(\bullet)$ Danish Holstein, and $(+)$ Jersey. The variables included are genetic parameters for mature weight $\left(\mathrm{W}_{\mathrm{M}}\right)$, $\mathrm{b}_{0}=$ rate of regaining body reserves per day, $\nu_{\mathrm{X}}=$ labile body mass mobilization index, $\nu_{\mathrm{y}}=$ peak milk yield potential, $\nu_{\mathrm{F}}=$ milk fat secretion, $\nu_{\mathrm{P}}=$ milk protein secretion, and $\nu_{\mathrm{L}}=$ milk lactose secretion. 
Table 4. Loadings and percent explained variance for principal components (PC) 1 to 7 in a PC analysis of genetic parameters for lifetime performance derived by fitting the GARUNS ${ }^{1}$ model to individual cow data ${ }^{2}$

\begin{tabular}{lrrrrrrr}
\hline Loadings & PC 1 & PC 2 & PC 3 & PC 4 & PC 5 & PC 6 & PC 7 \\
\hline $\mathrm{W}_{\mathrm{M}}$ & -0.74 & 0.56 & -0.20 & -0.01 & -0.03 & 0.31 & 0.04 \\
$\mathrm{~b}_{0}$ & -0.01 & 0.13 & 0.86 & 0.24 & 0.43 & 0.06 & 0.02 \\
$\nu_{\mathrm{x}}$ & 0.31 & 0.03 & -0.63 & 0.58 & 0.42 & 0.002 & -0.01 \\
$\nu_{\mathrm{y}}$ & -0.02 & -0.86 & 0.12 & 0.39 & -0.24 & 0.21 & -0.002 \\
$\nu_{\mathrm{F}}$ & 0.94 & -0.01 & -0.06 & -0.23 & 0.02 & 0.1 & 0.23 \\
$\nu_{\mathrm{P}}$ & 0.92 & 0.22 & 0.04 & -0.17 & -0.02 & 0.2 & -0.20 \\
$\nu_{\mathrm{L}}$ & 0.33 & 0.57 & 0.19 & 0.56 & -0.45 & -0.07 & 0.03 \\
$\%$ explained variance & 35.5 & 56.1 & 73.6 & 87.1 & 95.9 & 98.6 & 100 \\
\hline
\end{tabular}

${ }^{1}$ Growth $(\mathrm{G})$, aging $(A)$, regaining of body reserves (R), and energy supply of the unborn $(\mathrm{U})$, newborn $(\mathrm{N})$, and suckling $(\mathrm{S})$ calf over a lifespan.

${ }^{2} \mathrm{~W}_{\mathrm{M}}=$ nonlabile body mass at maturity; $\mathrm{b}_{0}=$ rate of regaining body reserves per day; $\nu_{\mathrm{X}}=$ labile body mass mobilization index; $\nu_{\mathrm{y}}=$ peak milk yield potential; $\nu_{\mathrm{F}}=$ milk fat secretion; $\nu_{\mathrm{P}}=$ milk protein secretion; and $\nu_{\mathrm{L}}=$ milk lactose secretion.

even negative $(\mathrm{r}=-0.01$ to 0.025$)$, indicating that selection for MY negligibly affects BW of an animal (Morris and Wilton, 1976; Brotherstone, 1994; Mason et al., 2009). However, Berry et al. (2003) reported that when BW was adjusted for BCS the correlation became positive and ranged from 0.15 to 0.39 . The negative correlation found in this study can be explained by the fact that $\mathrm{W}_{\mathrm{M}}$ was incorporated in the equation of milk production simulation aiming to scale MY to mature body size [i.e., genetic size-scaling rule (Taylor, 1972)]. Interestingly, the genetic scaling parameters controlling body reserve [mobilization $\left(v_{\mathrm{x}}\right)$ and accretion $\left(\mathrm{b}_{0}\right)$ ] were not significantly correlated within breed. Principal component 3 differentiated cows of high ability to mobilize body reserves from those of high ability to stor-

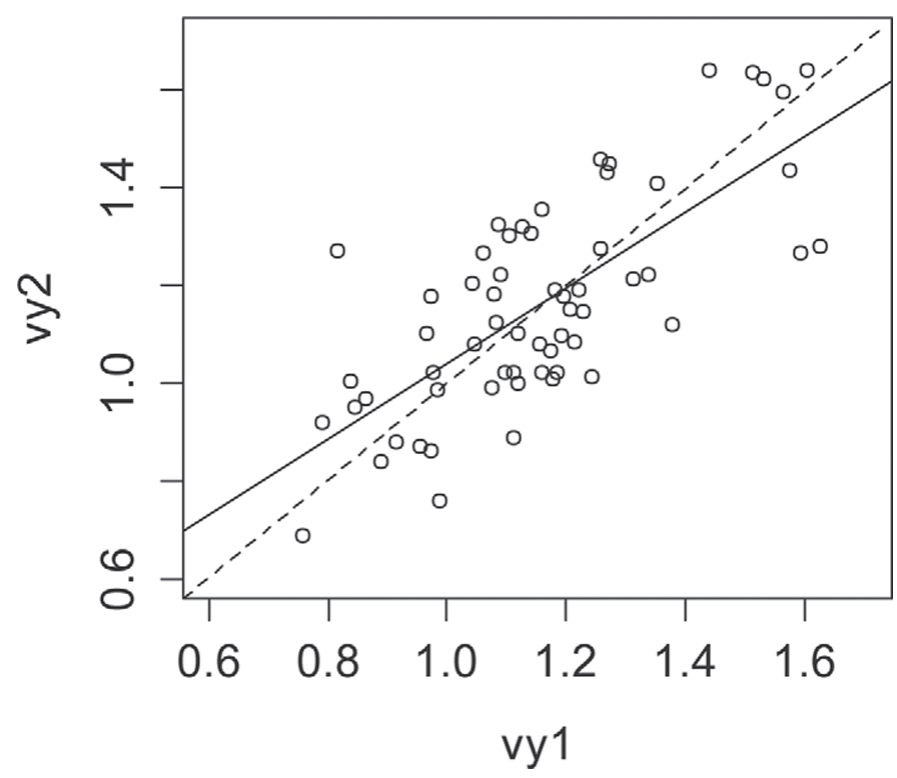

Figure 6. Scatter plot of the priority for milk production in parity 2 versus 1 . The $\nu_{\mathrm{y} 1}$ and $\nu_{\mathrm{y} 2}$ are priorities for milk production in parities 1 and 2, respectively. Dashed line: $\mathrm{y}=\mathrm{x}$, and solid line is linear regression of $v_{\mathrm{y} 1}$ on $\nu_{\mathrm{y} 2}$. age (Figure 5), which might imply differences between cows in the temporal pattern of nutrient partitioning that underpins lactation.

Another aspect of differences in the temporal pattern was found with respect to parity. Rather than assuming a fixed ratio between parities in the genetic scaling parameter for milk production, we allowed differences between animals in the ratio. As can be seen in Figure 6 , the priority for milk production in parity 2 tended to be impaired if it had been highly prioritized in the previous parity. However, this needs to be confirmed by a longer multi-lactation study.

\section{CONCLUSIONS}

The results of this study show the value of a dynamic model of lifetime performance as a tool to derive estimates of genetic potentials of MY, milk composition, body reserve usage, and growth for different genotypes of cow. The model was found, across a range of dairy breeds, to be sufficiently precise to be suitable for use in simulation studies of long-term efficiency. The correlations between model genetic parameters agreed with the related literature values, and also quantified some key components of variation in lactation performance. Thus, this model is a suitable basis for simulating the effects of genetic selection strategy on lifetime efficiency of individual cows, and thus address key questions about the impact of future selection (Dillon et al., 2006; Friggens et al., 2010; Berry and Crowley, 2013).

\section{ACKNOWLEDGMENTS}

The authors gratefully acknowledge the financial support of the GreenhouseMilk project. The GreenhouseMilk project is a Marie Curie Initial Training Network, funded by the European Commission, Framework 7 (Brussels, Belgium). 


\section{REFERENCES}

Baldwin, R. L., J. France, D. E. Beever, M. Gill, and J. H. M. Thornley. 1987a. Metabolism of the lactating cow: III. Properties of mechanistic models suitable for evaluation of energetic relationships and factors involved in the partition of nutrients. J. Dairy Res. 54:133-145.

Baldwin, R. L., J. France, and M. Gill. 1987b. Metabolism of the lactating cow: I. Animal elements of a mechanistic model. J. Dairy Res. 54:77-105.

Bauman, D. E., S. N. McCutcheon, W. D. Steinhour, P. J. Eppard, and S. J. Sechen. 1985. Sources of variation and prospects for improvement of productive efficiency in the dairy cow - A review. J. Anim. Sci. 60:583-592.

Bedö, S., E. Nikodémusz, K. Percsich, and L. Bárdos. 1995. Variations in the milk yield and milk composition of dairy cows during lactation. Acta Vet. Hung. 43:163-171.

Berry, D. P., F. Buckley, P. Dillon, R. D. Evans, M. Rath, and R. F. Veerkamp. 2003. Genetic Relationships among body condition score, body weight, milk yield, and fertility in dairy cows. J. Dairy Sci. 86:2193-2204

Berry, D. P., and J. J. Crowley. 2013. Genetics of feed efficiency in dairy and beef cattle. J. Anim. Sci. 91:1594-1613.

Brotherstone, S. 1994. Genetic and phenotypic correlations between linear type traits and production traits in Holstein-Friesian dairy cattle. Anim. Sci. 59:183-187.

Bryant, J., N. López-Villalobos, C. Holmes, J. Pryce, and N. LopezVillalobos. 2005. Simulation modelling of dairy cattle performance based on knowledge of genotype, environment and genotype by environment interactions: Current status. Agric. Syst. 86:121-143.

Cherwell Scientific Ltd. 2000. Modelmaker user manual. Cherwell Scientific Ltd., Oxford, UK.

Collard, B. L., P. J. Boettcher, J. C. M. Dekkers, D. Petitclerc, and L. R. Schaeffer. 2000. Relationships between energy balance and health traits of dairy cattle in early lactation. J. Dairy Sci. 83:2683-2690.

de Jager, D., and B. W. Kennedy. 1987. Genetic parameters of milk yield and composition and their relationships with alternative breeding goals. J. Dairy Sci. 70:1258-1266.

Dillon, P., D. P. Berry, R. D. Evans, F. Buckley, and B. Horan. 2006. Consequences of genetic selection for increased milk production in European seasonal pasture based systems of milk production. Livest. Sci. 99:141-158.

Dumas, A., J. Dijkstra, and J. France. 2008. Mathematical modelling in animal nutrition: A centenary review. J. Agric. Sci. 146:123-142.

Emmans, G., and I. Kyriazakis. 2001. Consequences of genetic change in farm animals on food intake and feeding behaviour. Proc. Nutr. Soc. 60:115-125.

Emmans, G. C., and C. Fisher. 1986. Problems in nutritional theory. Pages 9-39 in Nutrient Requirements of Poultry and Nutritional Research. C. Fisher and K. N. Boorman, ed. Butterworths, London, UK.

Erasmus, L., W. Smith, and P. Cronje. 2013. Feeding the lactating dairy cow to express its genetic potential. Accessed Nov. 10, 2013. https://www.touchlab.co.za/content/uploads/ ArticleDocument/1e7fd10f-36a8-4ed4-a112-1d84bd3a97c0.pdf.

Friggens, N. C. 2003. Body lipid reserves and the reproductive cycle: Towards a better understanding. Livest. Prod. Sci. 83:219-236.

Friggens, N.C., L. Brun-Lafleur, P. Faverdin, D. Sauvant, and O. Martin. 2013. Advances in predicting nutrient partitioning in the dairy cow: Recognizing the central role of genotype and its expression through time. Animal 7:89-101.

Friggens, N. C., C. Disenhaus, and H. V. Petit. 2010. Nutritional sub-fertility in the dairy cow: Towards improved reproductive management through a better biological understanding. Animal 4:1197-1213.

Fuentes-Pila, J., M. A. DeLorenzo, D. K. Beede, C. R. Staples, and J. B. Holter. 1996. Evaluation of equations based on animal factors to predict intake of lactating Holstein cows. J. Dairy Sci. $79: 1562-1571$

Garnsworthy, P. C. 2004. The environmental impact of fertility in dairy cows: A modelling approach to predict methane and ammonia emissions. Anim. Feed Sci. Technol. 112:211-223.
Heino, M., and V. Kaitala. 1999. Evolution of resource allocation between growth and reproduction in animals with indeterminate growth. J. Evol. Biol. 12:423-429.

Hoffman, P. C. 1997. Optimum body size of Holstein replacement heifers. J. Anim. Sci. 75:836-845.

Huhtanen, P. 2006. Effects of increasing the milk yield on milk composition. The International Skjervold-Symposium on Milk Quality, Oslo, Norway.

Jokela, J., and P. Mutikainen. 1995. Phenotypic plasticity and priority rules for energy allocation in a freshwater clam: A field experiment. Oecologia 104:122-132.

Kirkland, R. M., and F. J. Gordon. 2001. The effects of stage of lactation on the partitioning of, and responses to changes in, metabolisable energy intake in lactating dairy cows. Livest. Prod. Sci. $72: 213-224$

Lin, M., H. C. Lucas, and G. Shmueli. 2013. Research CommentaryToo big to fail: Large samples and the $P$-value problem. Inf. Syst. Res. 24:906-917.

Linn, J., M. Raeth-Knight, and N. Litherland. 2009. Role of feed (dairy) efficiency in dairy management. Pages 167-176 in Proc. 44th Pacific Northwest Anim. Nutr. Conf., Boise, Idaho.

Martin, O., and D. Sauvant. 2010a. A teleonomic model describing performance (body, milk and intake) during growth and over repeated reproductive cycles throughout the lifespan of dairy cattle. 1. Trajectories of life function priorities and genetic scaling. Animal 4:2030-2047.

Martin, O., and D. Sauvant. 2010b. A teleonomic model describing performance (body, milk and intake) during growth and over repeated reproductive cycles throughout the lifespan of dairy cattle. 2. Voluntary intake and energy partitioning. Animal 4:2048-2056.

Mason, I. L., A. Robertson, and B. Gjelstad. 2009. 661. The genetic connexion between body size, milk production and efficiency in dairy cattle. J. Dairy Res. 24:135-143.

Morris, C. A., and J. W. Wilton. 1976. Influence of body size on the biological efficiency of cows: A review. Can. J. Anim. Sci 56:613-647

Nielsen, H. M., N. C. Friggens, P. Lovendahl, J. Jensen, and K. L. Ingvartsen. 2003. Influence of breed, parity, and stage of lactation on lactational performance and relationship between body fatness and live weight. Livest. Prod. Sci. 79:119-133.

Oldham, J. D., and G. C. Emmans. 1989. Prediction of responses to required nutrients in dairy cows. J. Dairy Sci. 72:3212-3229.

Oltenacu, P. A., and B. Algers. 2005. Selection for increased production and the welfare of dairy cows: Are new breeding goals needed? Ambio 34:311-315.

Pantelić, V., M. M. Petrović, S. Aleksić, D. Ostojić, L. Sretenović, and Z. Novaković. 2008. Genetic correlations of productive and reproductive traits of Simmental cows in Republic of Serbia. Archiva Zootechnica 11:72-77.

R Development Core Team. 2014. The GNU Project. The R Project for Statistical Computing. Accessed Jan. 4, 2014. http://www. rproject.org/.

Schutz, M. M., L. B. Hansen, G. R. Steuernagel, and A. L. Kuck. 1990. Variation of milk, fat, protein, and somatic cells for dairy cattle. J. Dairy Sci. 73:484-493.

Stewart, P., R. Jones, and T. Dugmore. 2014. Practical Feeding of Dairy Cow. Accessed Jan. 5, 2014. http://agriculture.kzntl.gov za/AgricPublications/ProductionGuidelines/DairyinginKwaZulu Natal/PracticalFeedingoftheDairyCow/tabid/250/Default.aspx.

Taylor, C. S. 1972. Genetic differences in milk production in relation to mature body weight. Proc. Br. Soc. Anim. Prod. 2:15-25.

Vallas, M., H. Bovenhuis, T. Kaart, K. Pärna, H. Kiiman, and E. Pärna. 2010. Genetic parameters for milk coagulation properties in Estonian Holstein cows. J. Dairy Sci. 93:3789-3796.

Welper, R. D., and A. E. Freeman. 1992. Genetic parameters for yield traits of Holsteins, including lactose and somatic cell score. J Dairy Sci. $75: 1342-1348$.

Yan, T., C. S. Mayne, T. W. J. Keady, and R. E. Agnew. 2006. Effects of dairy cow genotype with two planes of nutrition on energy partitioning between milk and body tissue. J. Dairy Sci. 89:1031-1042. 


\section{APPENDIX}

Table A1. Estimates and standard errors of the regression coefficients for the mixed effect model between prediction residuals of BW, milk yield (MY), and DMI of Danish Red, Danish Holstein, and Jersey cows versus day from calving (DFC) and squared DFC

\begin{tabular}{|c|c|c|c|c|c|c|c|c|c|c|}
\hline \multirow[b]{2}{*}{ Variable } & \multirow[b]{2}{*}{ Breed $^{1}$} & \multicolumn{3}{|c|}{ Parity 1} & \multicolumn{3}{|c|}{ Parity 2} & \multicolumn{3}{|c|}{ Parity 3} \\
\hline & & Intercept & DFC & $\mathrm{DFC}^{2}$ & Intercept & DFC & $\mathrm{DFC}^{2}$ & Intercept & DFC & $\mathrm{DFC}^{2}$ \\
\hline \multirow[t]{3}{*}{ BW (kg) } & $\mathrm{DR}$ & $\begin{array}{c}0.568 \\
(1.658)\end{array}$ & $\begin{array}{r}-0.032^{\mathrm{a}} \\
(0.005)\end{array}$ & $\begin{array}{c}-3.7 \mathrm{E}-04^{*} \\
(3.3 \mathrm{E} 05)\end{array}$ & $\begin{array}{c}2.500 \\
(2.682)\end{array}$ & $\begin{array}{c}-0.006^{\mathrm{ab}} \\
(0.007)\end{array}$ & $\begin{array}{l}1.4 \mathrm{E}-04^{*} \\
(4 \mathrm{E}-05)\end{array}$ & $\begin{array}{c}6.297 \\
(6.734)\end{array}$ & $\begin{array}{r}-0.010^{\mathrm{a}} \\
(0.010)\end{array}$ & $\begin{array}{l}2.1 \mathrm{E}-04^{*} \\
(7 \mathrm{E}-05)\end{array}$ \\
\hline & $\mathrm{DH}$ & $\begin{array}{c}0.639 \\
(1.629)\end{array}$ & $\begin{array}{c}-0.064^{\mathrm{bc}} \\
(0.007)\end{array}$ & $\begin{array}{c}-3.7 \mathrm{E}-04^{*} \\
(3.3 \mathrm{E} 05)\end{array}$ & $\begin{array}{c}-2.001 \\
(2.742)\end{array}$ & $\begin{array}{r}-0.007^{\mathrm{a}} \\
(0.010)\end{array}$ & $\begin{array}{l}1.4 \mathrm{E}-04^{*} \\
(4 \mathrm{E}-05)\end{array}$ & $\begin{array}{l}13.385 \\
(6.732)\end{array}$ & $\begin{array}{r}0.013^{\mathrm{a}} \\
(0.015)\end{array}$ & $\begin{array}{l}2.1 \mathrm{E}-04^{*} \\
(7 \mathrm{E}-05)\end{array}$ \\
\hline & JR & -1.589 & $\begin{array}{r}-0.051^{\mathrm{c}} \\
(0.007)\end{array}$ & $\begin{array}{c}-3.7 \mathrm{E}-04^{*} \\
(3.3 \mathrm{E} 05)\end{array}$ & -0.126 & $-0.051^{b}$ & $1.4 \mathrm{E}-04^{*}$ & $\begin{array}{c}7.395 \\
(6.736)\end{array}$ & $-0.064^{b}$ & $2.1 \mathrm{E}-04^{*}$ \\
\hline \multirow[t]{4}{*}{$\mathrm{MY}(\mathrm{kg} / \mathrm{d})$} & $\mathrm{DR}$ & $\begin{array}{c}1.320^{\mathrm{ab}} \\
(0.250)\end{array}$ & $\begin{array}{l}0.053^{\mathrm{a}} \\
(3.6 \mathrm{E}-04)\end{array}$ & $\begin{array}{l}1.34 \mathrm{E}-04^{*} \\
(2.5 \mathrm{E}-06)\end{array}$ & $\begin{array}{r}(2.685) \\
0.672^{\mathrm{a}} \\
(0.198)\end{array}$ & $\begin{array}{l}\left(0.0095^{\mathrm{a}}\right. \\
(4.9 \mathrm{E}-04)\end{array}$ & $\begin{array}{c}(4 \mathrm{E}-05) \\
7 \mathrm{E}-05^{*} \\
(3 \mathrm{E}-06)\end{array}$ & $\begin{array}{l}(0.736) \\
1.243 \\
(0.473)\end{array}$ & $\begin{array}{l}(0.015) \\
0.029^{\mathrm{a}} \\
(8.1 \mathrm{E}-04)\end{array}$ & $\begin{array}{c}(7 \mathrm{E}-05) \\
\left(5 \mathrm{E}-05^{*}\right. \\
(06)\end{array}$ \\
\hline & $\mathrm{DH}$ & $\begin{array}{c}1.808^{\mathrm{a}} \\
(0.250)\end{array}$ & $\begin{array}{l}0.061^{\mathrm{b}} \\
(4.9 \mathrm{E}-04)\end{array}$ & $\begin{array}{l}1.24 \mathrm{E}-04^{*} \\
(2.5 \mathrm{E}-06)\end{array}$ & $\begin{array}{r}2.263^{\mathrm{b}} \\
(0.203)\end{array}$ & $\begin{array}{c}0.052^{\mathrm{b}} \\
(7 \mathrm{E}-04)\end{array}$ & $\begin{array}{c}7 \mathrm{E}-05^{*} \\
(3 \mathrm{E}-06)\end{array}$ & $\begin{array}{c}2.055 \\
(0.473)\end{array}$ & $\begin{array}{l}0.052^{\mathrm{b}} \\
(0.001)\end{array}$ & $\begin{array}{c}7 \mathrm{E}-05^{*} \\
(5 \mathrm{E}-06)\end{array}$ \\
\hline & JR & $0.954^{b}$ & $0.043^{\mathrm{c}}$ & $1.24 \mathrm{E}-04^{*}$ & $1.289^{c}$ & $0.038^{\mathrm{c}}$ & $7 \mathrm{E}-05^{*}$ & $\begin{array}{l}1.469 \\
1.09\end{array}$ & $0.039^{b}$ & $7 \mathrm{E}-05^{*}$ \\
\hline & & $(0.250)$ & (5.E-04) & $(2.5 \mathrm{E}-06)$ & $(0.199)$ & $(6 \mathrm{E}-04)$ & (3E-06) & $(0.473)$ & $(0.001)$ & $(5 \mathrm{E}-06)$ \\
\hline \multirow[t]{4}{*}{ DMI $(\mathrm{kg} / \mathrm{d})$} & DR & $\begin{array}{l}1.622^{\mathrm{ab}} \\
(0.212)\end{array}$ & $\begin{array}{l}0.022^{\mathrm{a}} \\
(5.8 \mathrm{E}-04)\end{array}$ & $\begin{array}{r}-4.8 \mathrm{E}-06^{*} \\
(38 \mathrm{E}-06)\end{array}$ & $\begin{array}{l}1.43^{\mathrm{a}} \\
(0.304)\end{array}$ & $\begin{array}{c}0.022^{\mathrm{a}} \\
(7 \mathrm{E}-04)\end{array}$ & $\begin{array}{r}-5 \mathrm{E}-05^{*} \\
(5 \mathrm{E}-06)\end{array}$ & $\begin{array}{l}1.475 \\
(0.511)\end{array}$ & $\begin{array}{r}0.023^{\mathrm{a}} \\
(0.001)\end{array}$ & $\begin{array}{c}-3.7 \mathrm{E}-05^{*} \\
(9 \mathrm{E}-06)\end{array}$ \\
\hline & $\mathrm{DH}$ & $2.073^{\mathrm{a}}$ & $0.028^{\mathrm{b}}$ & $-4.8 \mathrm{E}-06^{*}$ & $2.681^{\mathrm{b}}$ & $0.029^{\mathrm{b}}$ & $-5 \mathrm{E}-05^{*}$ & 2.111 & $0.029^{b}$ & $-3.7 \mathrm{E}-05^{*}$ \\
\hline & JR & $\begin{array}{l}(0.209) \\
1.176^{b}\end{array}$ & $\begin{array}{c}(8 \mathrm{E}-04) \\
0.029^{\mathrm{b}}\end{array}$ & $\begin{array}{r}(3.8 \mathrm{E}-06) \\
-4.8 \mathrm{E}-06^{*}\end{array}$ & $\begin{array}{l}(0.311) \\
2.196^{\mathrm{ab}}\end{array}$ & $\begin{array}{c}(0.001) \\
0.026^{c}\end{array}$ & $\begin{array}{r}(5 \mathrm{E}-06) \\
-5 \mathrm{E}-05^{*}\end{array}$ & $\begin{array}{l}(0.5 \Gamma 2) \\
1.373\end{array}$ & $\begin{array}{r}(0.002) \\
0.024^{\mathrm{a}}\end{array}$ & $\begin{array}{c}(9 \mathrm{E}-06) \\
-3.7 \mathrm{E}-05^{*}\end{array}$ \\
\hline & & $(0.213)$ & $(8 \mathrm{E}-04)$ & $(3.8 \mathrm{E}-06)$ & $(0.306)$ & $(0.001)$ & $(5 \mathrm{E}-06)$ & $(0.511)$ & $(0.002)$ & $(9 \mathrm{E}-06)$ \\
\hline
\end{tabular}

${ }^{a-c}$ Values with different superscripts within a column are significantly $(P<0.05)$ different.

${ }^{1} \mathrm{DR}=$ Danish Red; DH $=$ Danish Holstein; JR = Jersey. 
Table A2. Estimates and standard errors of the regression coefficients for the mixed effect model between prediction residuals of milk fat concentration (MCF), milk protein concentration (MCP), and milk lactose concentration (MCL) of Danish Red, Danish Holstein, and Jersey cows versus day from calving (DFC) and squared DFC

\begin{tabular}{|c|c|c|c|c|c|c|c|c|c|c|}
\hline \multirow[b]{2}{*}{ Variable } & \multirow[b]{2}{*}{ Breed $^{1}$} & \multicolumn{3}{|c|}{ Parity 1} & \multicolumn{3}{|c|}{ Parity 2} & \multicolumn{3}{|c|}{ Parity 3} \\
\hline & & Intercept & DFC & $\mathrm{DFC}^{2}$ & Intercept & $\mathrm{DFC}$ & $\mathrm{DFC}^{2}$ & Intercept & $\mathrm{DFC}$ & $\mathrm{DFC}^{2}$ \\
\hline \multirow[t]{5}{*}{$\mathrm{MCF}(\mathrm{kg} / \mathrm{kg})$} & DR & $\begin{array}{l}0.002^{\mathrm{a}} \\
\left(23 \mathrm{~F}_{-} \mathrm{O} 4\right.\end{array}$ & $-1.7 \mathrm{E}-05^{\mathrm{a}}$ & $-2.5 \mathrm{E}-07^{*}$ & $0.002^{\mathrm{a}}$ & $-2.7 \mathrm{E}-05^{\mathrm{a}}$ & $-2.1 \mathrm{E}-07^{*}$ & $\begin{array}{l}0.002 \\
\left(5-3 F_{-04}\right.\end{array}$ & $-3.5 \mathrm{E}-05^{\mathrm{a}}$ & $-2.3 \mathrm{E}-07^{*}$ \\
\hline & DH & $\begin{array}{c}(2.3 \mathrm{E}-04) \\
0.002^{\mathrm{a}}\end{array}$ & $2.2 \mathrm{E}-05^{\mathrm{b}}$ & $-2.5 \mathrm{E}-07^{*}$ & $\begin{array}{l}(3.1 \mathrm{E}-04) \\
0.002^{\mathrm{a}}\end{array}$ & $\begin{array}{r}(9.7 \mathrm{E}-07) \\
-2.7 \mathrm{E}-05^{\mathrm{a}}\end{array}$ & $\begin{array}{r}(7.0 \mathrm{E}-09) \\
-2.1 \mathrm{E}-07^{*}\end{array}$ & $\begin{array}{l}(5.3 \mathrm{E}-04) \\
0.001\end{array}$ & $\begin{array}{r}(1.6 \mathrm{E}-06) \\
-4.3 \mathrm{E}-05^{\mathrm{b}}\end{array}$ & $\begin{array}{c}(1.1 \mathrm{E}-08) \\
-2.3 \mathrm{E}-07^{*}\end{array}$ \\
\hline & & $(2.3 \mathrm{E}-04)$ & $(1.1 \mathrm{E}-06)$ & $(5.5 \mathrm{E}-09)$ & $(3.2 \mathrm{E}-04)$ & $(1.4 \mathrm{E}-06)$ & $(7.0 \mathrm{E}-09)$ & (5.3E-04) & $(2.2 \mathrm{E}-06)$ & $(1.1 \mathrm{E}-08)$ \\
\hline & JR & $0.003^{\mathrm{b}}$ & $5.0 \mathrm{E}-05^{\mathrm{c}}$ & $-2.5 \mathrm{E}-07^{*}$ & $0.003^{\mathrm{b}}$ & $7 \mathrm{E}-06^{\mathrm{b}}$ & $-2.1 \mathrm{E}-07^{*}$ & 0.002 & $5.0 \mathrm{E}-06^{\mathrm{c}}$ & $-2.3 \mathrm{E}-07^{*}$ \\
\hline & & $(2.3 \mathrm{E}-04)$ & (1.1E-06) & (5.5E-09) & $(3 \mathrm{E}-04)$ & $(1.3 \mathrm{E}-06)$ & (7.0E-09) & $(5.3 \mathrm{E}-04)$ & $(2.2 \mathrm{E}-06)$ & (1.1E-08) \\
\hline \multirow[t]{5}{*}{ MCP (kg/kg) } & DR & 0.001 & $-3.1 \mathrm{E}-05^{\mathrm{a}}$ & $-2 \mathrm{E}-07^{*}$ & 0.0013 & $-2.3 \mathrm{E}-05^{\mathrm{a}}$ & $-1.6 \mathrm{E}-07^{*}$ & 0.001 & $-2.4 \mathrm{E}-05^{\mathrm{a}}$ & $-2.2 \mathrm{E}-07^{*}$ \\
\hline & & $(1.9 \mathrm{E}-04)$ & (4.3E-07) & (3.1E-09) & $(2.1 \mathrm{E}-04)$ & (5.6E-07) & $(3.9 \mathrm{E}-09)$ & $(4.3 \mathrm{E}-04)$ & (7.3E-07) & (4.7E-09) \\
\hline & $\mathrm{DH}$ & 0.001 & $-2.8 \mathrm{E}-05^{\mathrm{b}}$ & $-2 \mathrm{E}-07^{*}$ & 0.0012 & $2.3 \mathrm{E}-05^{\mathrm{a}}$ & $-1.6 \mathrm{E}-07^{*}$ & 0.001 & $-3.2 \mathrm{E}-05^{\mathrm{b}}$ & $-2.2 \mathrm{E}-07^{*}$ \\
\hline & & $(1.9 \mathrm{E}-04)$ & (6.1E-07) & (3.1E-09) & $(2.2 \mathrm{E}-04)$ & (8.1E-07) & (3.9E-09) & $(4.3 \mathrm{E}-04)$ & (9.8E-07) & (4.7E-09) \\
\hline & JR & 0.001 & $\begin{array}{l}2.0 \mathrm{E}-05^{\mathrm{c}} \\
\left(5.9 \mathrm{~F}_{-}-07\right)\end{array}$ & $-2 \mathrm{E}-07^{*}$ & 0.0017 & $-2.1 \mathrm{E}-05^{\mathrm{b}}$ & $\begin{array}{l}-1.6 \mathrm{E}-07^{*} \\
\left(3.9 \mathrm{~F}_{-} 09\right)\end{array}$ & 0.002 & $-2.8 \mathrm{E}-05^{\mathrm{c}}$ & $-2.2 \mathrm{E}-07^{*}$ \\
\hline \multirow{6}{*}{ MCL $(\mathrm{kg} / \mathrm{kg})$} & DR & $4.9 \mathrm{E}-04^{*}$ & $1.3 \mathrm{E}-05^{\mathrm{a}}$ & $\begin{array}{l}(3.1 \mathrm{E}-09) \\
6.1 \mathrm{E}-08^{*}\end{array}$ & $\begin{array}{l}(2.1 \mathrm{E}-04) \\
-6.1 \mathrm{E}-04\end{array}$ & $-1.4 \mathrm{E}-06^{\mathrm{a}}$ & $\begin{array}{l}(3.9 \mathrm{E}-09) \\
4.6 \mathrm{E}-08^{*}\end{array}$ & $-0.001^{\mathrm{a}}$ & $\begin{array}{r}(1.0 \mathrm{E}-06) \\
-5.0 \mathrm{E}-06^{\mathrm{a}}\end{array}$ & $\begin{array}{r}(4.7 \mathrm{E}-09) \\
3.3 \mathrm{E}-08^{*}\end{array}$ \\
\hline & & $(2.04 \mathrm{E}-04)$ & $(2.3 \mathrm{E}-07)$ & $(1.6 \mathrm{E}-09)$ & $(2.3 \mathrm{E}-04)$ & $(2.7 \mathrm{E}-07)$ & $(1.9 \mathrm{E}-09)$ & $(3.1 \mathrm{E}-04)$ & $(5.2 \mathrm{E}-07)$ & (3.3E-09) \\
\hline & DH & $5.5 \mathrm{E}-04$ & $1.2 \mathrm{E}-05^{\mathrm{b}}$ & $6.1 \mathrm{E}-08^{*}$ & $-1.6 \mathrm{E}-04$ & $8.4 \mathrm{E}-06^{b c}$ & $4.6 \mathrm{E}-08^{*}$ & $-8.3 \mathrm{E}-04^{\mathrm{ab}}$ & $1.5 \mathrm{E}-06^{\mathrm{b}}$ & $3.3 \mathrm{E}-08^{*}$ \\
\hline & & $(2.05 \mathrm{E}-04)$ & (3.16E-07) & (1.6E-09) & $(2.4 \mathrm{E}-04)$ & $(3.9 \mathrm{E}-07)$ & (1.9E-09) & (3.1E-04) & $(6.9 \mathrm{E}-07)$ & (3.3E-09) \\
\hline & JR & $3.6 \mathrm{E}-04$ & $1.0 \mathrm{E}-05^{\mathrm{c}}$ & $6.1 \mathrm{E}-08^{*}$ & $-8.1 \mathrm{E}-05$ & $8.1 \mathrm{E}-06^{\mathrm{c}}$ & $4.6 \mathrm{E}-08^{*}$ & $-3.3 \mathrm{E}-05^{\mathrm{b}}$ & $2.2 \mathrm{E}-05^{\mathrm{c}}$ & $3.3 \mathrm{E}-08^{*}$ \\
\hline & & $(2.04 \mathrm{E}-04)$ & (3.1E-07) & $(1.6 \mathrm{E}-09)$ & $(2.3 \mathrm{E}-04)$ & (3.7E-07) & $(1.9 \mathrm{E}-09)$ & $(3.1 \mathrm{E}-04)$ & $(7.1 \mathrm{E}-07)$ & (3.3E-09) \\
\hline
\end{tabular}

${ }^{\mathrm{a}-\mathrm{C}}$ Values with different superscripts within a column are significantly $(P<0.05)$ different.

${ }^{1} \mathrm{DR}=$ Danish Red; DH = Danish Holstein; JR = Jersey.

${ }^{*} P<0.05$. 